\title{
PERSPEKTYWY UWOLNIENIA RYNKU GAZU ZIEMNEGO W POLSCE - KIERUNKI DZIAŁAŃ W LATACH 2012-2014
}

\section{Wprowadzenie}

W dobie dążenia państw Unii Europejskiej do stworzenia gospodarki niskoemisyjnej gaz ziemny staje się coraz ważniejszym surowcem energetycznym, stopniowo ograniczając znaczenie, jakie do tej pory miały w europejskim miksie energetycznym ropa naftowa, węgiel brunatny i kamienny oraz energia atomowa. Celem niniejszego opracowania jest zbadanie działań podejmowanych w Polsce w ostatnich kilku latach na rzecz uwolnienia rynku gazu, mającego szczególne znaczenie w budowaniu podstaw gospodarki niskoemisyjnej.

Mimo iż w ciągu ostatnich 3 lat zużycie gazu ziemnego w państwach Unii Europejskiej spadło, to przewiduje się, że w średniej i długiej perspektywie będzie ono rosnąć ${ }^{1}$. W pierwszych latach XXI w. oczekiwano szybkiego rozwoju sektora odnawialnych źródeł energii, którego uzupełnieniem miały być elektrownie gazowe. Zmiany te nie nastąpiły tak szybko, jak się spodziewano, a elektrownie gazowe nie są na chwilę obecną konkurencyjne w porównaniu chociażby z elektrowniami opalanymi węglem brunatnym ${ }^{2}$. Decyzje polityczne i uwarunkowania geograficzne sprawiają jednak, że w dłuższej perspektywie to właśnie gaz ziemny ma szansę zostać podstawowym surowcem energetycznym zapewniającym Unii Europejskiej możliwość dalszego rozwoju gospodarczego.

Utrzymujące się niskie ceny energii elektrycznej na rynkach hurtowych sprawiają, że w Polsce jej produkcja opłacalna jest przede wszystkim w blokach opalanych węglem, w szczególności zaś węglem brunatnym. Opłacalne jest również produkowanie energii elektrycznej z odnawialnych źródeł, jednak wyłącznie dzięki funkcjonowaniu kosztownego systemu ich wsparcia. Unia Europejska powinna wyznaczać

${ }^{1}$ International Energy Outlook 2011, U.S. Energy Information Administration, Washington, September 2011, s. 43.

${ }^{2}$ Drop in 2013 EU gas demand emphasises need for swift change, Eurogas Press Release, Brussels, 18 March 2014. 
światowe standardy. Przez stulecia to właśnie kraje dzisiejszej Unii Europejskiej były czołowymi gospodarkami świata i źródłem innowacyjności oraz rewolucji przemysłowej. Stawianie ambitnych celów i chęć stworzenia gospodarki niskoemisyjnej udowadniają, iż UE nadal chce wyznaczać trendy w światowej gospodarce. W dzisiejszym świecie w Unii Europejskiej powinno się jednak pamiętać o tym, że swoimi działaniami stawia się ona na przegranej pozycji w stosunku do tych graczy na arenie międzynarodowej, którzy przez dostęp do tańszej energii są bardziej konkurencyjni.

Zapewnienie konkurencyjności gazu ziemnego w branży elektroenergetycznej może pozwolić pogodzić ze sobą na pozór sprzeczne idee gospodarki niskoemisyjnej i konkurencyjności w stosunku do największych gospodarek świata. Dlatego też stworzenie wolnego rynku błękitnego paliwa obejmującego swym zasięgiem całą Unię Europejską powinno być priorytetem. Obecnie zachodzą procesy, które zmierzają do ukonstytuowania się światowego rynku gazu ziemnego. Dzięki nowym technologiom poszukiwania, wydobycia, a przede wszystkim transportu gazu ziemnego możliwe staje się ograniczenie uzależnienia odbiorców od regionalnych dostawców. Możliwe też staje się wyznaczanie cen gazu ziemnego przez wolny rynek, a nie - jak do tej pory - na podstawie cen produktów naftowych. Dzięki rozwojowi technologii Liquid Natural Gas (LNG) każde państwo mające dostęp do morza może importować błękitne paliwo z dowolnego kierunku. LNG, czyli skroplony gaz ziemny, jest paliwem produkowanym z gazu ziemnego. Podczas jego produkcji usuwane są zanieczyszczenia, po czym zmienia się stan skupienia gazu ziemnego przy wykorzystaniu wysokiego ciśnienia oraz niskiej temperatury. W wyniku owego procesu otrzymywane jest wyjątkowo czyste, pozbawione barwy, woni, własności toksycznych i korozyjnych paliwo, które po ogrzaniu można z powrotem przywrócić do stanu gazowego ${ }^{3}$.

Przy założeniu utrzymania polityki ograniczania emisji $\mathrm{CO}_{2}$ uwolnienie cen gazu, a przede wszystkim zniesienie monopolu w tym segmencie rynku powinno doprowadzić do zwiększenia konkurencyjności produkcji energii elektrycznej z błękitnego paliwa względem innych jej źródeł. Pewne działania mające na celu uwolnienie rynku gazu w Polsce zostały już podjęte, jednak wydają się one niewystarczające.

${ }^{3}$ http://polskielng.pl [dostęp 28.01.2014]. 


\section{Geneza procesów liberalizacji rynku gazu w Polsce}

Jako pierwszy kraj na świecie liberalizację rynku gazu przeprowadziły Stany Zjednoczone Ameryki. Proces ten trwał tam od 1978 r., kiedy to uchwalono Natural Gas Policy Act, zapewniający rozdzielenie działalności przesyłowej od innej działalności na rynku gazu i dostęp do infrastruktury na zasadzie Third Party Access (TPA), do pierwszej połowy lat 90. XX w. Zasada TPA polega na obowiązku udostępnienia przez właściciela bądź operatora infrastruktury przesyłowej tejże infrastruktury osobom trzecim, aby dostarczyć towary. Zasada ta ma na celu demonopolizację rynku. Już w 1985 r. uwolniono w USA ceny gazu, co stworzyło podstawy do uruchomienia otwartego dla inwestorów konkurencyjnego rynku gazu. W Europie pierwszym państwem, które poszło w ślady USA, była Wielka Brytania, która w 1986 r. zdecydowała się przeprowadzić proces prywatyzacyjny państwowego monopolisty w obszarze rynku gazu British Gas i powołała urząd regulacyjny Ofgas. Mimo prywatyzacji British Gas wciąż był monopolistą na rynku i dlatego też zdecydowano się na rozdział działalności sieciowej od sprzedaży. W 1995 r. uchwalono przepisy, na mocy których zliberalizowano rynek gazu i wprowadzono unbundling księgowy działalności sieciowej. Unbundling jest to rozdział działalności dystrybucyjnej od działalności wytwórczej. Udało się go ostatecznie wdrożyć w życie w 1997 r. ${ }^{5}$ W Europie kontynentalnej proces uwalniania rynku gazu rozpoczął się od przyjęcia pierwszej dyrektywy gazowej w $1998 \mathrm{r}$.

Państwa, które przystąpiły do Unii Europejskiej w latach 2004 i 2007, musiały przyjąć acquis communautaire, czyli porządek prawny UE, a więc i dyrektywy gazowe. Jednak specyfika tych państw była inna niż krajów „starej” Unii. Mimo wszystko $\mathrm{w}$ większości z nich rozpoczęto prywatyzację sektora gazowego przed przystąpieniem do UE. Wyjątkami były Bułgaria i Polska, w których państwo nadal sprawuje kontrolę własnościową nad wszystkimi szczeblami obrotu gazem i jego dystrybucji.

Rynek gazu w Polsce był do tej pory silnie zmonopolizowany i regulowany. Sytuacja ta podlega jednak obecnie przemianom, które swój początek biorą już w 2006 r., a jedne z najciekawszych wydarzeń na drodze ku tym zmianom dzieją się teraz na naszych oczach. Podejmowane działania zmierzają do liberalizacji i zwiększenia konkurencji na rynku gazu. Podobnie jak w innych państwach Unii Europejskiej,

${ }^{4}$ R. Zajdler, Perspektywy rozwoju formut cenowych $w$ kontraktach dtugoterminowych na dostawy gazu ziemnego oraz ich znaczenie dla stworzenia w Polsce hubu gazowego dla państw Europy Srodkowo-Wschodniej, Zajdler Energy Lawyers, Warszawa 2012, s. 19.

${ }^{5}$ Kierunki rozwoju ochrony konkurencji i konkurentów na rynku gazu w Polsce, Urząd Ochrony Konkurencji i Konsumentów, Warszawa, sierpień 2012, s. 29. 
zmiany mają obejmować obszar handlu hurtowego i detalicznego, rozumianego jako sprzedaż gazu odbiorcom końcowym. Docelowo zmiany mają umożliwić potencjalnym uczestnikom rynku, którzy otrzymają odpowiednią koncesję, handel gazem ziemnym. Odbiorcom końcowym ma natomiast zostać umożliwiony zakup gazu od wybranego przez nich sprzedawcy zgodnie z zasadą TPA. Głównymi dokumentami, które określały postulowane tempo i charakter zmian, były: Mapa drogowa uwolnienia cen gazu ziemnego, opracowana przez prezesa URE, Program uwalniania gazu (PUG), opracowany przez Polskie Górnictwo Naftowe i Gazownictwo SA (PGNiG SA) z 13 lutego 2012 r., oraz opracowany przez Ministerstwo Gospodarki projekt ustawy - Prawo gazowe. Kluczowym podmiotem realizacji uwolnienia cen gazu w Polsce jest Towarowa Giełda Energii SA (TGE SA), która ma umożliwiać handel gazem ziemnym na zasadach wolnego rynku.

Pierwszym krokiem na drodze ku liberalizacji rynku gazu była decyzja prezesa URE z 18 grudnia 2006 r., na mocy której spółka GAZ-SYSTEM SA została operatorem polskiego systemu przesyłowego. Spółka ta jest własnością Skarbu Państwa i odpowiada za bezpieczeństwo dostaw gazu sieciami przesyłowymi. Kolejnym krokiem było oddzielenie spółek zajmujących się działalnością dystrybucyjną od innych spółek gazowych, co nastąpiło z dniem 1 lipca 2007 r. Stanowiło to również spełnienie bardzo ważnego wymogu nałożonego na Polskę przez Unię Europejską.

Do tego czasu obrót gazem ziemnym był realizowany jedynie przez kontrakty bilateralne. Gazem nie można było natomiast handlować na giełdzie ani w węzłach wymiany handlowej. Mimo iż w Polsce istnieją poza PGNiG inne przedsiębiorstwa posiadające odpowiednie koncesje, ich udział w rynku wynosi jedynie $2 \%$ w stosunku do $98 \%$ państwowego giganta ${ }^{6}$. Sytuację taką można bez wątpienia nazwać monopolem, który nie jest korzystny dla cen gazu, a więc zarówno polskiej gospodarki, jak i odbiorców końcowych. Widać, że mimo wprowadzania do polskiego prawa części wymogów unijnych obrót gazem jest nadal silnie zmonopolizowany. Dzieje się tak m.in. dlatego, że PGNiG skupia w swojej grupie kapitałowej niemal wszystkie rodzaje działalności związanej z dostarczaniem odbiorcom gazu ziemnego. Jedynym wyjątkiem jest działalność przesyłowa, którą zajmuje się GAZ-SYSTEM SA. Sytuację komplikuje też fakt, iż 70\% zapotrzebowania na gaz ziemny jest pokrywane z jednego kierunku - z Rosji, a gaz ten importuje właśnie PGNiG, które ponadto jest właścicielem większości źródeł krajowych. Sytuacja taka w znaczny sposób utrudnia prowadzenie konkurencji cenowej między dostawcami i samo wejście nowych dostawców na rynek. W praktyce zatem to PGNiG ustalało taryfy dla paliw gazowych, a kontrolę nad ich wysokością sprawował jedynie prezes URE, do którego należało ich zatwierdzanie.

\footnotetext{
${ }^{6}$ M. Kulesa, P. Rogóż, Wybrane uwarunkowania liberalizacji sektora gazu w Polsce, „Profesjonalne Gazownictwo" 2011/2012, s. 11.
} 
Jak szacuje TGE SA, docelowo zainteresowanych udziałem w rynku gazu może być ponad 50 podmiotów, wśród których znajdują się spółki już dziś handlujące na małą skalę, przemysłowi odbiorcy gazu na dużą skalę, tacy jak chociażby przedsiębiorstwa chemiczne, przedsiębiorstwa energetyczne czy spółki obrotu energią․ Obecnie na TGE jest 13 podmiotów bezpośrednio dopuszczonych do handlu na rynku gazu. Należy jednak zwrócić uwagę na fakt, że wśród nich są domy maklerskie, które mogą zawierać transakcje w imieniu klienta i na rachunek własny. Uwzględniając klientów domów maklerskich, należy stwierdzić, że liczba podmiotów uczestniczących w rynku gazu za pośrednictwem TGE wynosi już $24^{8}$. Liczba ta jednak systematycznie rośnie i docelowo może osiągnąć prognozowane wartości.

\section{Działania regulacyjne w latach 2011-2014}

Wyjściowym dokumentem określającym proponowany docelowy system obrotu gazem i kroki, jakie należy podjąć do jego osiągnięcia, była Mapa drogowa uwolnienia cen gazu ziemnego, opracowana przez URE9 . Zawierała ona program działań, których podjęcie umożliwiłoby zmiany systemowe na rynku gazu prowadzące do rozwoju konkurencji i uwolnienia cen gazu ziemnego. Program zarysowany w mapie drogowej miał również na celu harmonizację polskiego rynku gazu z rynkiem europejskim, co miało zaowocować wzrostem bezpieczeństwa energetycznego państwa i całej Unii.

Mapa drogowa miała umożliwić ${ }^{10}$ :

- zmianę struktury podmiotowej występującej na rynku gazu i uwolnienie cen gazu ziemnego dla odbiorców przemysłowych od 1 stycznia 2013 r.,

- rozwój przejrzystego hurtowego rynku gazu ziemnego oraz stworzenie mechanizmów zmiany sprzedawcy dla odbiorców detalicznych między 2013 a 2014 r., a także uwolnienie cen gazu dla gospodarstw domowych od początku 2015 r.,

- ogólnounijne ujednolicenie zasad, na jakich funkcjonują rynki i instytucje rynkowe na podstawie kodeksów sieciowych opracowanych przez ACER i European Network of Transmission System Operators for Gas (ENTSOG), zrzeszającą operatorów systemów przesyłowych z UE (z polskiej strony jest to GAZ-SYSTEM SA),

- wzmocnienie pozycji odbiorców końcowych.

\footnotetext{
7 Ibidem, s. 10.

${ }^{8}$ Stan na dzień $14.03 .2014 \mathrm{r}$.

9 Prezes Urzędu Regulacji Energetyki, Mapa drogowa uwolnienia cen gazu ziemnego - projekt, Warszawa, 22 sierpnia 2012.

${ }^{10}$ Kierunki rozwoju ochrony konkurencji..., op.cit., s. 67.
} 
Mapa drogowa wraz z Rekomendacjami dla programu uwalniania gazu ziemnego $w$ Polsce, z dnia 15 listopada 2011 r. również wydanymi przez prezesa URE, i Wynikami badania ankietowego przeprowadzonego przez prezesa URE z 30 września 2011 r. były podstawą do stworzenia przez PGNiG Programu uwolnienia gazu. Przy tworzeniu tego programu czerpano również z doświadczenia innych państw członkowskich UE w tym zakresie. Wśród tych państw znalazły się m.in.: Wielka Brytania, Francja, Niemcy, Hiszpania i Czechy. Wzięto też pod uwagę Wytyczne organizacji branżowych odnośnie do zasad realizacji programów uwalniania gazu, które zostały przygotowane przez European Federation of Energy Traders, i Uzasadniona opinię Komisji Europejskiej skierowana do Rzeczypospolitej Polskiej w związku z naruszeniem zapisów Dyrektywy Parlamentu Europejskiego i Rady 2009/73/WE z dnia 13 lipca 2009 r. ${ }^{11}$

Program uwolnienia gazu jest znanym i powszechnym w Europie narzędziem wspierania liberalizacji rynku gazu oraz rozwiązywania problemów związanych zarówno z nierównomiernym i ograniczonym dostępem do dostaw gazu ziemnego, jak i z możliwością jego przesyłania czy magazynowania. Dzięki programom tego rodzaju na rynek mogą wejść podmioty niemające dostępu do własnych źródeł wydobycia czy też importu. Przy czym programy takie stosuje się najczęściej we wczesnej fazie istnienia rynku, by wspomóc jego rozwój - szczególnie w sytuacji, gdy na danym rynku istnieje monopol, a ewentualna konkurencja jest ograniczona. „Podstawowym wyznacznikiem prawidłowo i celowo przeprowadzonego programu uwalniania gazu jest jego rola jako »katalizatora « w kontekście wdrażania i rozwoju konkurencyjnego, transparentnego oraz płynnego rynku gazu"12.

Podstawowym celem programu uwolnienia gazu jest zatem zmuszenie monopolisty lub przedsiębiorstwa dominującego na rynku do hurtowej odsprzedaży danej ilości posiadanego przez niego surowca w zorganizowany sposób. „Sposobem osiągnięcia konkurencyjnego rynku gazu jest zapewnienie właściwej płynności rynku pozwalającej na skuteczną grę sił popytu i podaży oraz zapewnienie właściwej przejrzystości mechanizmów tego rynku, która zapewni większą wiarygodność sposobu wyznaczania cen, a zatem zwiększy zaufanie uczestników do rynku”"13.

Programy uwalniania gazu przeprowadziła większość państw europejskich, a w szczególności państwa członkowskie UE. Biorąc pod uwagę sytuację rynkową, ze szczególnym uwzględnieniem pozycji monopolisty na rynku, trzeba stwierdzić, że podobne programy przeprowadziły państwa takie, jak Włochy, Hiszpania, Francja, Niemcy czy Wielka Brytania. Biorąc jednak pod uwagę kontekst geopolityczny,

${ }^{11}$ Program uwolnienia gazu. Projekt do publicznych konsultacji, Polskie Górnictwo Naftowe i Gazownictwo S.A., Warszawa, 13 lutego 2012, s. 3.

12 M. Kulesa, P. Rogóż, op.cit., s. 12.

${ }^{13}$ R. Zajdler, op.cit., s. 19. 
należy zwrócić szczególną uwagę na programy uwolnienia gazu przeprowadzone w Republice Czeskiej i na Węgrzech.

Opracowana przez PGNiG koncepcja PUG zakładała podzielenie rynku gazu na trzy segmenty ${ }^{14}$ :

- rynek PUG - sprzedaż w ramach aukcji organizowanej za pośrednictwem TGE SA gazu ziemnego innym hurtowym uczestnikom rynku w celu jego dalszej odsprzedaży na rynku hurtowym,

- rynek hurtowy - obejmujący dalszą odsprzedaż gazu przez przedsiębiorstwa uczestniczące uprzednio w aukcjach PUG, a także importerów i spółki wydobywcze,

- rynek detaliczny - w skład którego wchodzą odbiorcy końcowi, podzieleni na odbiorców instytucjonalnych (komercyjnych) i gospodarstwa domowe.

Sposób działania rynku gazu opisany przez PUG prezentuje rysunek 1.

Rysunek 1. Kształt rynku gazu po jego uwolnieniu opisujący przepływy między jego poszczególnymi segmentami według PUG

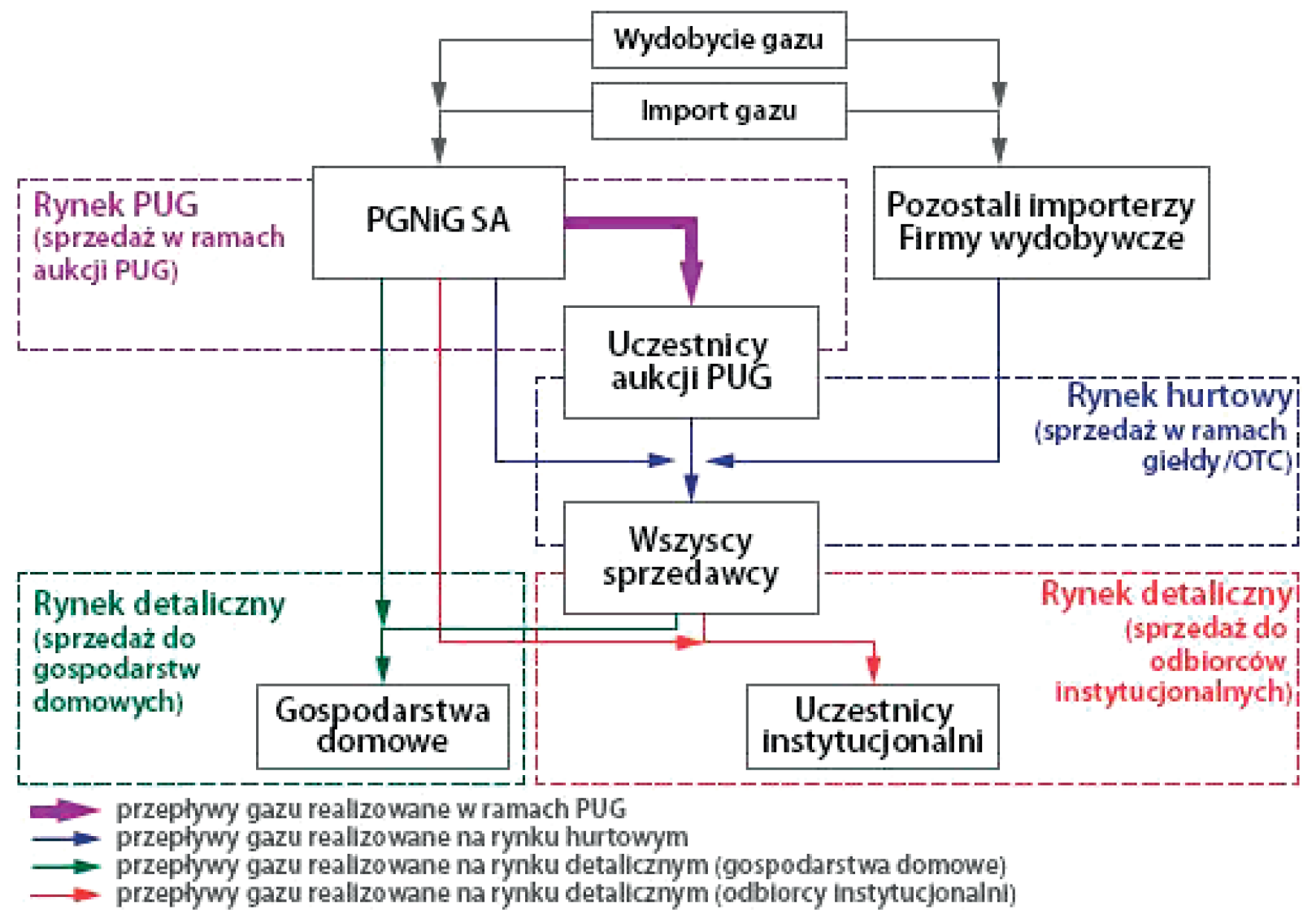

Źródło: M. Kulesa, P. Rogóż, Wybrane uwarunkowania liberalizacji sektora gazu w Polsce, „Profesjonalne Gazownictwo" 2011/2012, s. 14.

14 Program uwolnienia gazu..., op.cit., s. 9. 
W koncepcji przedstawionej przez PGNiG założono, że na rynku pierwotnym, czyli w ramach aukcji PUG, mieli brać udział jedynie uczestnicy hurtowi, którzy mieli nabywać gaz w celu jego dalszej odsprzedaży. W aukcjach na lata 2013-2015 dostępny miał być wolumen gazu sięgający do $70 \%$ wielkości rynku, co oznacza wielkość rzędu 9,4 mld $\mathrm{m}^{3}$ rocznie ${ }^{15}$. Handel miał się odbywać w seriach aukcji, po 5 aukcji z rzędu w dwutygodniowych odstępach raz w roku. W ten sposób w każdej $\mathrm{z}$ aukcji udostępniane miało być $1,9 \mathrm{mld}^{3}$ gazu, stanowiące około $14 \%$ rynku. W owych aukcjach PGNiG nie mogłoby występować jako podmiot kupujący, natomiast spółek zależnych od PGNiG to ograniczenie miało już nie dotyczyć. Sposób przeprowadzania aukcji miał gwarantować równy dostęp wszystkim zainteresowanym podmiotom na takich samych zasadach. Udostępnienie gazu następowałoby $\mathrm{w}$ wirtualnym punkcie w obrębie systemu przesyłowego GAZ-SYSTEM. Kontrakty oferowane $\mathrm{w}$ omawianym systemie aukcji byłyby umowami rocznymi $\mathrm{z}$ terminem rozpoczęcia dostawy od pierwszego stycznia w latach 2013, 2014, $2015 \mathrm{w}$ transzach po $10000 \mathrm{MWh}$, co odpowiada ok. $1 \mathrm{mln} \mathrm{m}^{3}$ gazu ziemnego rocznie. Miały to być kontrakty o stałym profilu dostawy (kontrakt typu BASE z dostawą określonej ilości gazu ziemnego w każdej godzinie doby, w każdym dniu roku).

Cena dostawy dla pierwszego kwartału wykonania danego kontraktu rocznego miała być ustalana jako cena na aukcji. Dla kolejnych kwartałów danego roku cena miała być indeksowana zgodnie z porozumieniem regulacyjnym zawartym przez PGNiG i prezesa URE ${ }^{16}$. Zawarcie owego porozumienia było jednym $z$ ważniejszych założeń omawianego modelu działania rynku gazu. Miało ono określać metodologię kalkulacji ceny w ramach aukcji PUG, cena ta odnosiłaby się do pierwszego kwartału wykonania kontraktu oraz sposobu indeksacji cen przez PGNiG w ramach PUG w kolejnych kwartałach wykonania kontraktu. Cena wyjściowa oferowana na aukcji przez PGNiG miała być wyliczana na podstawie: kosztów ponoszonych przez PGNiG dla całego portfolio importowanego przez spółkę gazu, kosztów ponoszonych przy pozyskiwaniu gazu ze źródeł krajowych obejmujących zwrot z kapitału, kosztów utrzymywania obowiązkowych zapasów gazu ziemnego, opłat naliczanych przez GAZ-SYSTEM SA za wprowadzenie surowca do systemu przesyłowego oraz marży hurtowej $\mathrm{PGNiG}^{17}$. Cena ta mogłaby ewentualnie podlegać modyfikacjom w procesie przeprowadzania aukcji, jednak w ramach tych modyfikacji możliwy byłby jedynie wzrost ceny. Sama cena na aukcji miała być wyznaczana w tzw. mechanizmie ceny ofertowej (pay-as-bid), który jest korzystniejszy dla oferenta niż dla kupującego. Aby

\footnotetext{
15 Ibidem, s. 6.

16 Ibidem, s. 12.

17 M. Kulesa, P. Rogóż, op.cit., s. 13.
} 
dokonać zakupu na aukcji PUG, zainteresowany podmiot musiałby określić liczbę jednostek, jaką jest zainteresowany, oraz cenę, jaką jest skłonny zapłacić, przy czym na aukcję byłyby przyjmowane jedynie zlecenia w cenie wyższej niż cena wyjściowa aukcji ${ }^{18}$. W mechanizmie pay-as-bid cena transakcyjna dla wolumenów zakupionego gazu jest równa cenie określonej przez kupującego w zleceniu. Zlecenia są realizowane w ten sposób, że zaczyna się od tych o najwyższej cenie, a kończy na tym, które osiąga cenę graniczną, przy czym każde ze zleceń jest realizowane po cenie zaoferowanej przez kupującego. Zlecenia poniżej ceny granicznej nie zostaną zrealizowane ${ }^{19}$. Rysunek 2 ilustruje mechanizm przydziału gazu na aukcjach PUG.

\section{Rysunek 2. Mechanizm przydziału gazu w ramach aukcji PUG}

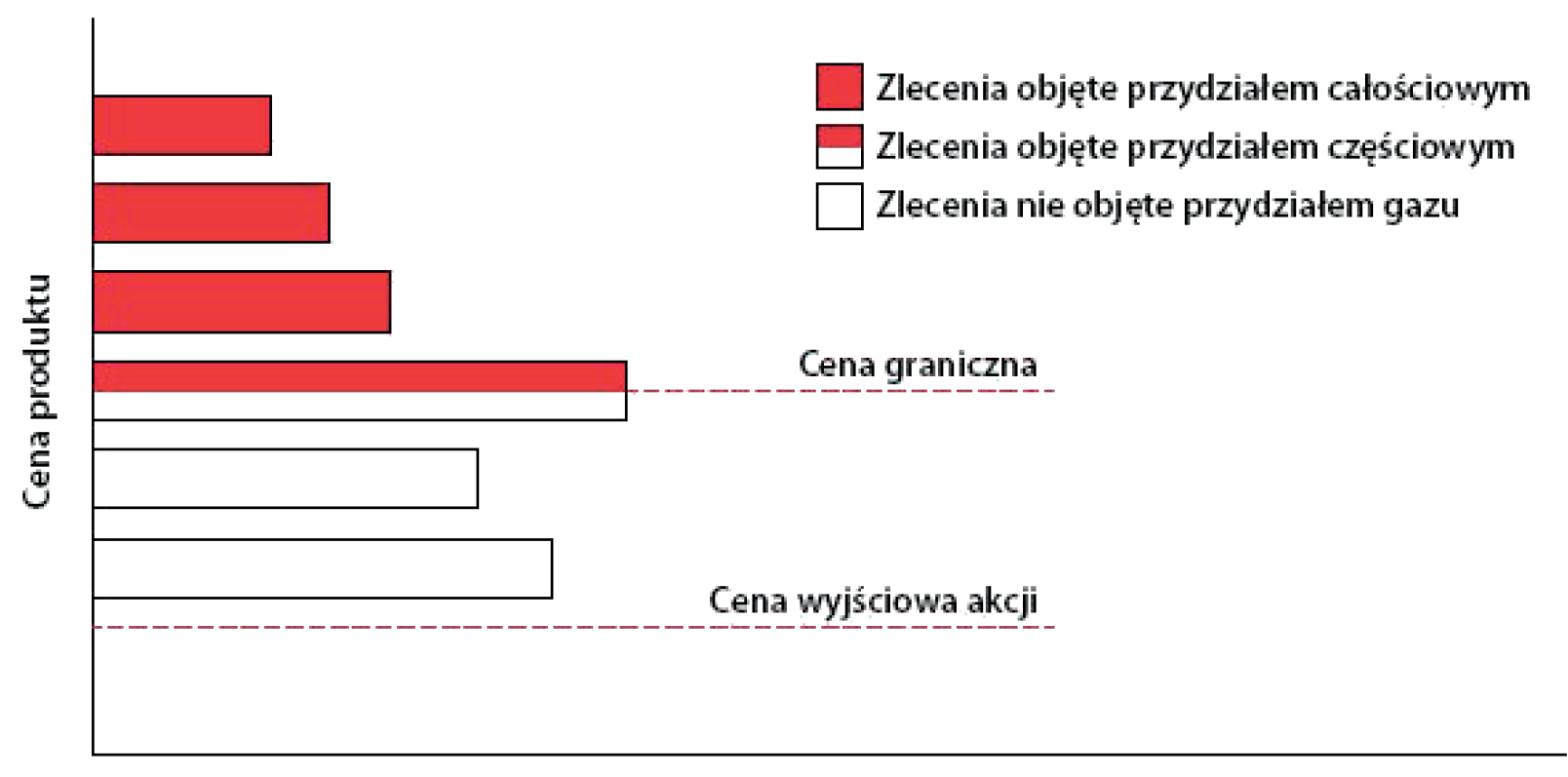

Wolumen zleceń zakupu

Źródło: Program uwolnienia gazu. Projekt do publicznych konsultacji, Polskie Górnictwo Naftowe i Gazownictwo S.A., Warszawa, 13 lutego 2012, s. 18.

Uruchomienie aukcji pozwoliłoby na stworzenie na TGE rynku wtórnego (rynku hurtowego), zapewniającego możliwość swobodnego handlu gazem ziemnym. PGNiG zaproponowało obrót w ramach rynku wtórnego prowadzony na rynku giełdowym, ale również w ramach kontraktów bilateralnych.

Projekt PUG po ogłoszeniu podlegał konsultacjom społecznym mającym na celu poznanie oczekiwań zainteresowanych stron i wnoszenie przez nie uwag. Wśród kwestii mogących stanowić problem w realizacji programu wskazywano krótki czas

18 Program uwolnienia gazu..., op.cit., s. 18.

19 Y. Ren, F.D. Galiana, Pay-as-bid vs. Marginal Pricing, Mc Gill University, Montreal 2003, s. 7-8. 
trwania PUG (3 lata, podczas gdy w innych państwach europejskich tego typu programy były obliczone na 4 do 5 lat), możliwość brania udziału w aukcjach PUG przez spółki zależne PGNiG, brak określonego trybu postępowania po upływie czasu, na jaki przewidywano PUG, i - co chyba najważniejsze - fakt, iż PUG został stworzony przez spółkę, w której interesie nie leży uwalnianie rynku. W innych państwach europejskich programy tego typu były tworzone i przeprowadzane przez organy rządowe, regulatora rynku bądź Komisję Europejską. PGNiG w oczywisty sposób jest zainteresowane tym, by inne przedsiębiorstwa miały ograniczoną możliwość konkurowania czy wejścia na rynek ${ }^{20}$.

Mimo pozornego zaawansowania prac nad programem, zakładane w nim rozpoczęcie aukcji 1 stycznia 2013 r. stawało się coraz mniej realne. W wyniku krytycznych uwag do programu zgłaszanych przez zarówno zainteresowane strony, jak i Komisję Europejską 28 maja 2012 r. prezes URE przedstawił koncepcję obliga giełdowego, odnoszącego się do handlu gazem ziemnym. Wprowadzenie obliga giełdowego jest równoznaczne ze zobowiązaniem producentów i importerów gazu do sprzedaży określonej ilości wprowadzanego do obrotu gazu za pośrednictwem giełdy. Tym sposobem można stworzyć płynny rynek hurtowy, na którym kształtowałyby się rynkowe ceny surowca. Podobne regulacje obowiązują w odniesieniu do energii elektrycznej i pozwoliły na stworzenie płynnego rynku energii elektrycznej na TGE SA. Obecnie obligo giełdowe w przypadku energii elektrycznej wynosi 15\%, jednak wiele przedsiębiorstw dobrowolnie sprzedaje jej więcej za pośrednictwem giełdy (zgodnie z art. 49a pkt 1 ustawy z dnia 10 kwietnia 1997 r. - Prawo energetyczne, Dz. U. z 1997 r. Nr 54, poz. 348).

W omawianym projekcie prezes URE założył dwa etapy uruchamiania giełdy. Pierwszy z nich miał polegać na rozpoczęciu handlu giełdowego gazem ziemnym w 2012 r. PGNiG miało jako animator rynku oferować wolumeny gazu, na jakie zgłaszaliby zapotrzebowanie uczestnicy rynku. Na tym etapie koniecznym działaniem miało być dostosowanie prawa i procedur dotyczących sektora gazowego. Niezbędne zmiany dotyczyły Instrukcji ruchu i eksploatacji sieci dystrybucyjnej (IRiESD), Instrukcji ruchu i eksploatacji sieci przesyłowej (IRiESP) oraz Regulaminu Towarowej Giełdy Energii SA. Kolejnym koniecznym krokiem miało być podpisanie między TGE a PGNiG porozumienia w sprawie animowania rynku gazu, dzięki czemu uruchomiony miał zostać obrót gazem. Rozpoczęcie tego obrotu było datowane już na III kwartał 2012 r. Wynika z tego, iż pierwszy etap uwalniania rynku gazu miał zostać przeprowadzony bez zmian ustawowych ${ }^{21}$.

${ }^{20}$ Kierunki rozwoju ochrony konkurencji..., op.cit., s. 72.

${ }^{21}$ Ibidem, s. 76. 
$\mathrm{Na}$ drugim etapie planowano znowelizowanie ustawy - Prawo energetyczne. Obligo giełdowe miało zostać nałożone na podmioty o istotnym udziale w rynku. Założono, że nowelizacja ustawy obejmie przede wszystkim kwestie takie, jak: zniesienie taryf gazowych dla odbiorców instytucjonalnych, wprowadzenie obliga giełdowego w wysokości co najmniej 70\% ilości gazu wprowadzanego do sieci przez dużych uczestników rynku gazu i publikacja średnich cen gazu w kontraktach importowych ${ }^{22}$.

Ostatecznie pomysł wprowadzenia rynku pierwotnego i wtórnego gazu upadł, a liberalizację rynku gazu zaczęto wprowadzać bez umocowania ustawowego na podstawie istniejącego prawa, zmieniając jedynie odpowiednie rozporządzenia, instrukcje i regulaminy. Należy zwrócić uwagę na fakt, iż procesy związane z uwalnianiem rynku gazu stymuluje przede wszystkim Komisja Europejska, która - po wielu monitach w sprawie wprowadzenia w życie III pakietu energetycznego - ostatecznie 21 listopada 2012 r. złożyła do Trybunału Sprawiedliwości Unii Europejskiej w Luksemburgu wniosek o nałożenie kary na Polskę za brak implementacji prawa unijnego w tym zakresie. Kara miałaby wynieść 88 819,2 euro dziennie ${ }^{23}$. Dlatego też 24 lipca 2012 r. nastąpiło zatwierdzenie IRiESP przez prezesa URE. Nowa instrukcja weszła w życie z dniem 1 stycznia 2013 r. ${ }^{24}$ Prezes URE zadecydował również, że od tego samego dnia weszła w życie nowa IRiESD.

Następnie, 30 października 2012 r., prezes URE uznał, iż rynek gazu na TGE jest rynkiem konkurencyjnym. Jak czytamy w wydanej przez niego informacji: „Rynek gazu ziemnego organizowany przez giełdę towarową działającą zgodnie z ustawą o giełdach towarowych oraz rynek organizowany przez podmiot prowadzący na terytorium Rzeczypospolitej Polskiej rynek regulowany z mocy prawa spełnia warunki konkurencyjnego segmentu rynku gazu"25. Decyzja ta miała kluczowe znaczenie dla liberalizacji rynku gazu.

Wcześniej, bo już 28 sierpnia 2012 r., minister gospodarki wydał rozporządzenie zmieniające rozporządzenie w sprawie szczegółowych warunków funkcjonowania systemu gazowego. Mocą nowego rozporządzenia umożliwiono obrót gazem w punkcie wirtualnym. Od tego czasu przedsiębiorstwo przesyłające paliwa gazowe ma obowiązek świadczyć sprzedawcy usługę między punktem wejścia surowca do systemu przesyłowego a punktem wirtualnym. Dla odbiorcy usługa ma być świadczona

\footnotetext{
22 Ibidem.

${ }^{23} \mathrm{http}$ ///ebe.org.pl/aktualnosci/polska/komisja-europejska-domaga-sie-kary-dla-polski-grozi-nam-ponad-1-mln-euro-za-kazdy-tydzien-opoznienia-we-wdrozeniu-dyrektyw.html [dostęp 28.12.2012].

${ }^{24} \mathrm{http}: / /$ www.gaz-system.pl/strefa-klienta/iriesp/instrukcja-ruchu-i-eksploatacji-sieci-przesylowej [dostęp 20.01.2013].

25 Prezes Urzędu Regulacji Energetyki, Informacja nr 29 w sprawie braku obowiązku przedkładania do zatwierdzania taryf na obrót paliwami gazowymi na giełdzie towarowej, Warszawa 2012.
} 
natomiast między punktem wejścia surowca do systemu przesyłowego a punktem wirtualnym (zgodnie z rozporządzeniem Ministra Gospodarki z dnia 20 sierpnia 2012 r. zmieniającym rozporządzenie w sprawie szczegółowych warunków funkcjonowania systemu gazowego, Dz. U. z 2012 r. poz. 968). Ostatnim koniecznym elementem było wprowadzenie przez TGE SA z dniem 13 września 2012 r. nowego Regulaminu obrotu rynku towarów giełdowych, w którym znalazły się zapisy regulujące aspekty związane z rynkiem gazu.

Zgodnie $\mathrm{z}$ kalendarzem notowań, notowania TGE rozpoczęto $\mathrm{z}$ dniem 20 grudnia 2012 r. W obrocie znalazły się miesięczne, kwartalne i roczne instrumenty typu BASE, z pierwszym dniem dostawy 1 stycznia 2013 r. zgodnie z IRiESP i IRiESD. Od 31 grudnia 2012 r. w obrocie znajduje się też kontrakt BASE typu spot z dostawą na dzień następny.

Sukcesem TGE jest fakt, iż już pierwszego dnia notowań zawarto pierwszą transakcję na Rynku Towarowym Terminowym Gazu, na jeden kontrakt miesięczny z dostawą w styczniu 2013 r. Oznacza to transakcję na 744 MWh, czyli ok. 82 tys. m³ gazu.

11 września 2013 r. wprowadzono tzw. mały trójpak energetyczny. Na mocy jego postanowień weszło w życie okrojone w stosunku do pierwotnych założeń obligo giełdowe na gaz. W pierwszym roku obowiązywania regulacji PGNiG musiało wprowadzić do sieci nie mniej niż 30\% wysokometanowego gazu ziemnego za pośrednictwem TGE. W 2014 r. wielkość obliga wzrosła do 40\%, by osiągnąć w 2015 r. docelową wartość 55\% (zgodnie z art. 25 ustawy z dnia 26 lipca 2013 r. o zmianie ustawy - Prawo energetyczne oraz niektórych innych ustaw, Dz. U. z 2013 r. poz. 984). Zapisy te miały pozwolić na osłabienie monopolistycznej pozycji PGNiG na polskim rynku i wzmocnić spółki działające na rynku gazu oraz zachęcić nowe do wejścia na ten rynek.

Jak się jednak szybko okazało, PGNiG nie sprostało nałożonemu na nie zobowiązaniu. Zgodnie z zapisami małego trójpaku energetycznego, w 2013 r. spółka powinna sprzedać za pośrednictwem TGE około $1,4 \mathrm{mld}^{3}$ gazu ziemnego, sprzedała jednak jedynie nieco ponad $200 \mathrm{mln}^{3}$ gazu $^{26}$. Przyczyny zaistniałego stanu rzeczy są wieloaspektowe. Jedną z nich jest fakt, że PGNiG ma podpisane wieloletnie umowy dwustronne na dostawy błękitnego paliwa. Obrót wolumenami dostarczanymi na podstawie takich umów jest już niemożliwy na parkiecie TGE. W praktyce PGNiG nie jest w stanie sprzedać za pośrednictwem giełdy gazu, nawet oferując go w cenie niższej od cen w kontraktach dwustronnych. Okazuje się, że monopolistyczna pozycja

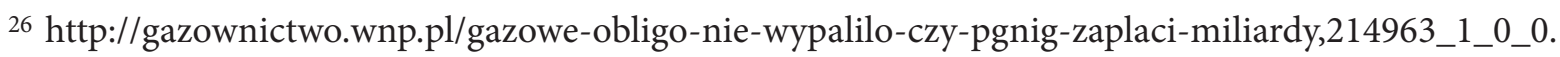
html [dostęp 14.02.2014].
} 
spółki nie pozwala jej na wypełnienie obliga. Sam monopolista skarży się na fakt, iż ma problem ze znalezieniem chętnych do zakupu gazu za pośrednictwem giełdy. Do pewnego stopnia podyktowane jest to istniejącymi taryfami na gaz.

Jak wynika z przytoczonych danych, PGNiG wywiązało się z obliga w 2013 r. jedynie w ok. 15\%. Należy też zwrócić uwagę na fakt, iż część wolumenu, który spółce udało się sprzedać za pośrednictwem giełdy, sprzedała ona swoim spółkom córkom. Teoretycznie istnieje możliwość nałożenia na PGNiG kar w wysokości do 15\% przychodów za niewywiązywanie się z obliga. W obecnej sytuacji taki scenariusz wydaje się jednak mało prawdopodobny.

Obecnie na TGE są prowadzone prace nad nowymi produktami, które będą dostępne na rynku gazu. Stworzenie nowych produktów, w tym rynku intra day, ma ułatwić PGNiG wywiązanie się z nałożonych na nie obowiązków i wpłynąć pozytywnie na rynek, zwiększając jego atrakcyjność dla innych uczestników.

Po wprowadzeniu nowych produktów PGNiG będzie miało pełen wachlarz możliwości sprzedaży gazu za pośrednictwem giełdy, składający się z instrumentów forward $\mathrm{z}$ dostawą fizyczną w okresie od 1 miesiąca do 2 lat, oraz rynek intra day. Należy zwrócić uwagę na fakt, iż istnieje również możliwość organizowania aukcji na danym produkcie giełdowym. Aukcje takie opierają się na opisywanym już mechanizmie pay-as-bid i są dla PGNiG doskonałym narzędziem do wypełniania obligo.

Stworzenie wolnego, transparentnego rynku gazu jest zadaniem bardzo trudnym. By osiągnąć pożądane cele, należy zadbać o dywersyfikację dostaw surowca m.in. dzięki budowie interkonektorów z państwami graniczącymi z Polską i budowie gazoportu w Świnoujściu. Trzeba rozwijać wydobycie gazu ze źródeł własnych i docelowo znieść taryfy na gaz. Należy też tworzyć nowe instrumenty na rynku gazu, tak by jak najlepiej sprostać zapotrzebowaniu uczestników rynku. Jednak te wszystkie skomplikowane i niejednokrotnie bardzo kosztowne działania nie przyniosą pożądanego skutku w postaci wykrystalizowania się płynnego rynku gazu tak długo, jak długo na rynku będzie istniał monopol.

Istnienie PGNiG jako silnego podmiotu gospodarczego, zdolnego do inwestycji $\mathrm{w}$ segmencie upstream i do konkurowania oraz współpracy z największymi potentatami na europejskich i światowych rynkach, jest konieczne z punku widzenia polskiego bezpieczeństwa energetycznego ${ }^{27}$. Należy jednak znieść monopolistyczną pozycję owej spółki na polskim rynku gazu.

Pogodzenie celu, jakim jest stworzenie płynnego rynku gazu, z zachowaniem silnego PGNiG nie będzie łatwe, ale jest możliwe. Wystarczy przeprowadzić podobne działania, jakie miały miejsce przy uwalnianiu rynku energii elektrycznej. Potrzebne

27 Upstream - branża poszukiwania, wydobycia i przetwórstwa ropy naftowej oraz gazu ziemnego. 
jest wprowadzenie realnej konkurencji w segmencie sprzedaży surowca klientom końcowym.

W obecnej sytuacji wszystkie inne działania prawdopodobnie nie doprowadzą do stworzenia rynku gazu, ponieważ PGNiG prowadzi działalność we wszystkich segmentach rynku poza przesyłem, który zresztą też jeszcze niedawno należał do tej spółki. Jeżeli niemal całość rynku należy do PGNiG, praktycznie nie ma możliwości, żeby na rynek weszli nowi gracze, co jest warunkiem koniecznym tego, by rynek stał się płynny i wyznaczał ceny. Dzisiaj nawet jeśli przedsiębiorstwo zakupi gaz za pośrednictwem giełdy, po korzystnej skądinąd cenie, w praktyce nie ma możliwości odsprzedania tego gazu, ponieważ to PGNiG dostarcza surowiec niemal wszystkim klientom końcowym.

By zmienić ten stan rzeczy, należy ułatwić innym przedsiębiorstwom wejście na rynek. Jedną z przeszkód dla potencjalnych nowych uczestników rynku jest uzyskanie dwóch koncesji - jednej na obrót krajowy (obrót paliwami gazowymi) i drugiej na import gazu (obrót gazem $\mathrm{z}$ zagranicą). W tym przypadku nawet stworzenie jednej koncesji i przyspieszenie procedur byłoby znacznym ułatwieniem. Ponadto istnieje problem $z$ dostępem do infrastruktury magazynowej. Każde przedsiębiorstwo importujące powyżej $100 \mathrm{mln} \mathrm{m}^{3}$ gazu ziemnego rocznie lub obsługujące powyżej 100 tys. odbiorców końcowych musi utrzymywać minimalne zapasy gazu ziemnego. Sam obowiązek utrzymywania obowiązkowych rezerw jest zrozumiały - są one konieczne na wypadek ograniczenia lub wstrzymania dostaw surowca. Należy jednak umożliwić nowym potencjalnym uczestnikom rynku dostęp do zdolności magazynowania. By to osiągnąć, z jednej strony należy rozbudowywać magazyny, z drugiej zaś Operatorem Systemu Magazynowania nie powinna być spółka należąca do PGNiG. Powinna ona zostać wydzielona ze struktur PGNiG tak, jak stało się to z Operatorem Systemu Przesyłowego, by nie było wątpliwości co do niezależności spółki względem usługodawców.

Podstawowym sposobem na zniesienie monopolu jest jednak zmuszenie PGNiG nie tylko do rozdzielenia działalności wydobywczej i importu od sprzedaży oraz wydzielenia Operatora Systemu Magazynowania ze swoich struktur, ale również do odsprzedania znacznej części działu sprzedaży w dużych pakietach innym firmom. Nie ulega wątpliwości, że znajdą się chętni do nabycia części działalności sprzedażowej. W sytuacji, w której będzie działać kilka podmiotów sprzedających duże wolumeny gazu klientom końcowym, będzie można mówić o istnieniu rynku. Gdy do tego doda się zniesienie taryf, rynek w końcu będzie miał szansę być wolny. Dzisiaj taryfy dla klientów końcowych są potrzebne dlatego, że PGNiG jest monopolistą i taryfy są jedynym narzędziem niepozwalającym spółce na dowolne kształtowa- 
nie cen. Gdyby na rynku była konkurencja, a PGNiG miałoby tylko część udziałów w sprzedaży klientom końcowym, taryfy przestałyby być potrzebne.

Działanie takie nie musiałoby oznaczać pogorszenia sytuacji spółki. Pieniądze ze sprzedaży części przedsiębiorstwa mogłyby zostać zainwestowane w segment upstream, który generuje największe zyski, lub w przejęcia na rynkach europejskich czy światowych. PGNiG nadal pozostałoby jedną z największych spółek w kraju, posiadającą wystarczający kapitał, by prowadzić projekty wydobywcze lub akwizycje. Jednocześnie możliwe byłoby stworzenie prawdziwego rynku gazu, na którym przedsiębiorstwa konkurowałyby ze sobą, co prowadziłoby do wyznaczania cen w sposób rynkowy. Gdy do tego doliczymy zwiększenie liczby kierunków i sposobów importu surowca, i ewentualne zwiększenie wydobycia krajowego dzięki poszukiwaniom zarówno złóż konwencjonalnych, jak i niekonwencjonalnych, Polska może stać się hubem gazowym dla regionu Europy Centralnej, a PGNiG - najważniejszą tego typu spółką w regionie.

\section{Zakończenie}

Rynek gazu w Polsce przez wiele lat był stabilny i nie podlegał większym zmianom. Istnienie państwowego monopolisty na tym rynku było akceptowane przez kolejne rządy, a może nawet było korzystne z punktu widzenia państwa, jak i „zasiedziałego" monopolisty. Od czasu wejścia Polski do Unii Europejskiej sytuacja ta zaczęła ulegać zmianom. Nie tyle zmieniło się podejście rządzących czy też monopolisty, ile zostali oni zmuszeni przez UE do rozpoczęcia liberalizacji rynku gazu w Polsce. Procesy te przebiegały dotychczas powoli, raczej ewolucyjnie niż rewolucyjnie. Od czasu wejścia w życie III pakietu energetycznego UE zaczęła zdecydowanie silniej naciskać na polski rząd, by ten uwolnił rynek gazu. Znamienne jest to, że to PGNiG stworzyło program uwolnienia rynku gazu, a oczywisty jest fakt, że proces ten z punktu widzenia samej spółki nie jest korzystny, nawet jeśli może się okazać, że spółka na nim zyska. Działania, których celem jest stworzenie wolnego rynku gazu w Polsce, nabrały w ostatnim czasie dynamiki niemającej precedensu. Nie zważając na to, iż jest to efektem nacisku z zewnątrz, należy uznać zachodzące procesy za korzystne dla polskiej gospodarki. Wolny rynek gazu zwiększy poziom bezpieczeństwa energetycznego państwa, co w dzisiejszych czasach jest wyjątkowo ważnym aspektem. Pozwoli również rozwinąć się branży, co oznacza utworzenie nowych miejsc pracy. Przede wszystkim doprowadzi jednak do ustalania cen na podstawie wielkości podaży i popytu, a więc w sposób rynkowy. Nawet jeżeli będzie 
to oznaczało chwilowe podniesienie cen dla odbiorców końcowych po zniesieniu taryf, w długiej perspektywie stanie się to korzystne dla wszystkich zainteresowanych stron.

W układance tworzącej się zarówno z wprowadzonych już zmian, jak i z tych, które są obecnie opracowywane, brakuje tylko jednego kluczowego elementu. Jest nim stworzenie konkurencji na rynku i pozwolenie innym niż PGNiG podmiotom gospodarczym na wejście na rynek i odgrywanie na nim poważnej roli. Sposobem na to, by wprowadzić ten postulat w życie, jest zmuszenie PGNiG do odsprzedania części firmy zajmującej się sprzedażą surowca klientom końcowym. Sprzedaż zorganizowanych części przedsiębiorstwa innym podmiotom gospodarczym zapewni konkurencję na rynku i pozwoli realnie rozwinąć handel na Towarowej Giełdzie Energii. W takiej sytuacji PGNiG nie miałoby już problemu $\mathrm{z}$ wypełnieniem obligo giełdowego, a pozyskane $\mathrm{w}$ ten sposób środki mogłoby zainwestować $\mathrm{w}$ projekty związane $\mathrm{z}$ wydobyciem czy przejęciami.

Ponadto należy ułatwić dostęp do infrastruktury magazynowania gazu spółkom innym niż PGNiG. Wydaje się, iż do osiągnięcia tego celu wystarczy wydzielić ze struktur PGNiG Operatora Systemu Magazynowania, tak jak wcześniej wydzielono OSP, oraz prowadzić dalsze inwestycje w obszarze infrastruktury magazynowania gazu ziemnego. Pomocne byłoby również stworzenie jednej koncesji na obrót krajowy oraz import gazu z zagranicy.

Obraz wyłaniający się z analizy polskiego rynku gazu jest nieczytelny. Polska stanęła w pół drogi do utworzenia prawdziwie wolnego rynku gazu, na którym cena surowca byłaby wyznaczana przez popyt i podaż. W przypadku zmian dotyczących rynku gazu grupa interesariuszy jest bardzo szeroka, a potężne grupy interesu lobbują za rozwiązaniami dla siebie korzystnymi. Dlatego też prowadząca do pełnej liberalizacji droga, która została do pokonania, jest długa. Obecnie panuje jednak wyjątkowo dobry klimat dla takich zmian w związku z wydarzeniami na Ukrainie i projektem Unii Energetycznej. Najważniejszym celem utworzenia takiej unii powinno być stworzenie paneuropejskich rynków energii elektrycznej i gazu ziemnego, a podstawowym sposobem do ich osiągnięcia jest rozbudowa infrastruktury przesyłowej i magazynowej oraz umożliwienie wolnego handlu między państwami Unii Europejskiej. Do realizacji tego celu w pierwszej kolejności potrzebne jest dokończenie uwalniania rynku gazu w Polsce. 


\section{Towards the liberalisation of the natural gas market in Poland (2012-2014)}

The aim of this paper is to analyse recent actions undertaken in Poland with the purpose of liberalising the natural gas market. It seems that the drive towards a liberalised natural gas market has been dynamic in Poland in recent years, especially due to the strong EU pressure after the introduction of the third energy package.

Keywords: low-carbon economy, natural gas market liberalisation, economic competitiveness

\section{Vers la libéralisation du marché du gaz naturel en Pologne (2012-2014)}

Le but de cet article est d'analyser les actions récentes menées en Pologne qui visent à la libéralisation du marché du gaz naturel. Il semble que le mouvement vers le marché du gaz naturel libéralisé a été dynamique en Pologne au cours des dernières années, notamment en raison de la forte pression de l'UE après le Troisième paquet énergie.

Mots-clés: léconomie sobre en carbone, la libéralisation du marché du gaz naturel, la compétitivité économique

\section{В сторону либерализации рынка природного газа в Польше (2012-2014)}

Целью данной работы является анализ недавних действий, предпринятых в Польше, направленных на либерализацию рынка природного газа. Кажется, что в Польше, в последние годы, стремление к либерализации рынка природного газа является мощным, особенно в связи с сильным давлением ЕС после третьего энергетического пакета.

Ключевые слова: низкоуглеродная экономика, либерализация рынка природного газа, экономическая конкурентоспособность 